Magdalena MUSIAŁ-KARG

Uniwersytet im. Adama Mickiewicza, Poznań

\title{
Metody zwiększania frekwencji wyborczej. Polska a doświadczenia innych państw
}

\section{Wstęp}

W Spółczesna demokracja parlamentarna stoi w obliczu kryzysu, który przejawia się m.in. w wadliwie funkcjonujących najważniejszych instytucjach państwowych, które nie spełniają we właściwy sposób swoich podstawowych funkcji. W konsekwencji takiego stanu obserwuje się spadek społecznego zaufania względem organów władzy. Jedną z najważniejszych oznak kryzysu demokracji jest zmniejszający się systematycznie poziom frekwencji wyborczej w elekcjach państwowych, w referendach, a także w wyborach o charakterze ponadnarodowym. Raporty i analizy dotyczące poziomu frekwencji wyborczej odnotowują światową tendencję spadku partycypacji obywateli w wyborach. Jak zauważa Ola Pettersson, „,według tych źródeł coraz mniej obywateli pojawia się przy urnach wyborczych" ". Tendencję tę potwierdza Jacek Raciborski, pisząc, iż „z frekwencją wyborczą w wielu demokracjach są kłopoty, w Polsce szczególnie wielkie". Autor zwraca przy tym uwagę na fakt, iż jedną z najważniejszych konsekwencji nikłego uczestnictwa obywateli w procedurach wyborczych jest poważny deficyt legitymizacyjny ${ }^{2}$.

Wiele państw próbuje temu zapobiec, podejmując różne działania mające na celu zapobieżenie spadaniu frekwencji, a wręcz przeciwnie - zwiększenie jej poziomu, co wpłynęłoby na wzrost poziomu legitymacji podejmowanych decyzji politycznych.

1 O. Pettersson, Rola instytucji publicznych i organizacji pozarzadowych w przekazywaniu obywatelom informacji o wyborach - przykłady działań z różnych krajów, International IDEA, tekst przygotowany na seminarium ,Jak skutecznie informować obywateli o wyborach?", Instytut Spraw Publicznych, Warszawa, 19 czerwca 2009, s. 3 .

2 J. J. Wiatr, J. Raciborski, J. Bartkowski, B. Frątczak-Rudnicka, J. Kilias, Demokracja Polska 1989-2003, Warszawa 2003, s. 208. 
W Polsce niski poziom frekwencji jest często podejmowanym tematem - szczególnie tuż przed wyborami krajowymi. Warto zatem zastanowić się nad przyczynami absencji Polaków przy urnach wyborczych oraz nad sposobami poradzenia sobie z tym problemem. Celem pracy jest odpowiedź na pytanie o metody zwiększania frekwencji wyborczej, jakie stosowane są w różnych państwach, w tym w Polsce. Ze względu na rozległość podejmowanego tematu oraz trudność w dostępie do szczegółowych danych z poszczególnych państw, w niniejszym tekście nie będzie dokonana analiza zmian frekwencji w wyniku zastosowania poszczególnych rozwiązań.

\section{Koncepcje uczestnictwa. Frekwencja. Absencja}

Debata na temat aktywności politycznej wyborców w wielu państwach na świecie, w tym w Polsce - jako młodej demokracji - prowadzona jest od wielu lat. Zasadniczym jej celem jest poznanie czynników, które decydują o tym, że przeciętny obywatel, decyduje się nie brać udziału w głosowaniu.

We współczesnej refleksji nad demokracją wyróżnia się dwa główne sposoby patrzenia na rolę uczestnictwa wyborczego. Oba podejścia związane są z (partycypacyjną) klasyczną teorią demokracji oraz (elitarystyczną) rewizjonistyczną teorią demokracji ${ }^{3}$.

Dla partycypacjonistów najistotniejszym z elementów porządku demokratycznego jest współudział obywateli w sprawowaniu władzy państwowej. Wzorem, do którego się odwołuja, jest grecka polis. Robert A. Dahl, prowadząc rozważania na temat klasycznej demokracji nawiązuje do jej greckiego źródłosłowia - demos i kratos (rządy ludu), zwracając uwagę, że istotą demokracji jest aktywność, udział ludu w sprawowaniu władzy. Pisząc o klasycznej demokracji - Dahl stwierdza, że „oznaczała ona przede wszystkim bezpośredni udział obywateli; demokracja albo jest partycypacyjna, albo jej w ogóle nie ma. Zgodnie ze stara tradycją Rousseau twierdził, że aby obywatele byli w pełni suwerenni, muszą mieć możliwość gromadzenia się i uczestniczenia we wspólnym

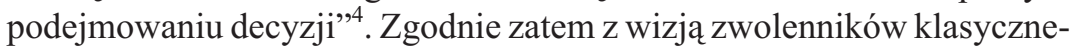
go pojmowania partycypacji wyborczej - uczestniczenie obywateli w ży-

3 M. Cześnik, Uczestnictwo wyborcze, stosunek do demokracji, legitymizacja władzy. Przypadek Polski, w: Populizm a demokracja, red. R. Markowski, Warszawa 2004, s. 124.

4 R. Dahl, Demokracja i jej krytycy, Kraków 1995, s. 316. 
ciu politycznym jest najistotniejszym celem demokracji, gdyż ich udział w sprawowaniu władzy legitymizuje system demokratyczny, a obywatele mogą wówczas się samorealizować.

Seymour Martin Lipset zwracając uwagę na związek między poziomem uczestnictwa i legitymizacji, potwierdza to podejście pisząc, iż państwo, „,w którym duża część społeczeństwa jest bierna, niezainteresowana i nieświadoma" narażone jest na brak przyzwolenia, a także na ograniczoną możliwość wypracowania konsensu. Niska frekwencja i brak partycypacji odzwierciedlają nieistnienie ukształtowanego społeczeństwa obywatelskiego ${ }^{5}$. Tej wizji uwagę poświęca również Arend Lijphart, według którego partycypacja wyborcza jest najważniejszym sposobem aktywności obywateli i przypisuje jej wręcz fundamentalne znaczenie dla równości - jako podstawowej wartości demokracji ${ }^{6}$.

Z kolei druga wspomniana teoria demokracji - elitarystyczna, nazywana także teorią demokracji jako konkurencji, bazuje na współzawodnictwie między elitami. Jej przedstawicielem jest Joseph Schumpeter, którego zdaniem rola obywateli w demokracji jest ograniczona, a podział na wyborców i pochodzących z wyborów polityków ma istotne znaczenie - wyborcy bowiem winni uwzględniać wytworzony w wyniku elekcji podział pracy. „Nie mogą zbyt pochopnie wycofać swojego zaufania między wyborami, muszą też zrozumieć, że kiedy już ktoś został wybrany to on ma się zajmować robotą polityczną a nie oni"7.

Należy przy tym zaznaczyć, iż w tym przypadku nie przypisuje się znaczącej roli zdolnościom przeciętnych obywateli do partycypowania w życiu politycznym. Uczestnictwo obywateli w sprawowaniu władzy ograniczone zostało do brania udziału w procedurze wybierania przedstawicieli. Zgodnie z tym podejściem wysoka frekwencja w głosowaniach może czasami wpływać negatywnie na demokrację. Lipset wskazuje, iż ta szkoła myślenia niską frekwencję interpretuje jako „dowód ogólnego zadowolenia elektoratu z istniejącego stanu rzeczy" ${ }^{\prime 8}$. Obywatele nie chodzą do urn, ponieważ ich zdaniem system funkcjonuje prawidłowo, nie ma dla niego zagrożeń, nie ma więc bodźców motywujących do uczestnictwa w głosowaniu. Za odpowiedni przykład uznać można Szwajcarię, gdzie fre-

5 S. M. Lipset, Homo Politicus. Spoleczne podstawy polityki, Warszawa 1995, s. 231.

6 A. Lijphart, Unequal Participation. Democracy's Unresolved Dilemma, „American Political Science Review" 1997, nr 1, s. 1-14.

7 J. Schumpeter, Kapitalizm. Socjalizm. Demokracja, Warszawa 1995, s. 367-368.

${ }^{8}$ S. M. Lipset, Homo Politicus..., s. 232. 
kwencja w głosowaniach na szczeblu federacji jest relatywnie niska - na poziomie 35-50\%. Pomimo tego demokracja w tym kraju działa prawidłowo, a Szwajcaria jest uznawana wręcz za wzór państwa demokratycznego.

$\mathrm{Z}$ punktu widzenia niniejszego tekstu bardzo przydatnym dla prowadzonych rozważań jest termin frekwencja wyborcza, którą określa się na ogół jako stosunek oddanych głosów do liczby obywateli zarejestrowanych w celu głosowania w wyborach. Chociaż - jak zaznacza Pettersson - w literaturze specjalistycznej znaleźć można również bardziej wszechstronne sposoby mierzenia frekwencji wyborczej, jednak ,wspomniana metoda jest często stosowana, gdyż opiera się na danych liczbowych, które są zazwyczaj łatwo dostępne"".

Arkadiusz Żukowski pisze, iż frekwencja - w najprostszym i zarazem najczęściej spotykanym ujęciu - oznacza odsetek osób uprawnionych do głosowania, które oddają swój głos w wyborach bądź w referendach. Wyrażana jest procentowym stosunkiem liczby wyborców, którzy oddali głosy (ważne i nieważne) do liczby wyborców uprawnionych do głosowania ${ }^{10}$.

Badając frekwencję wyborczą w różnych elekcjach warto uzmysłowić sobie, iż wolne i uczciwe wybory (free and fair elections) nie są automatycznie synonimem demokracji. Z kolei wysoki poziom partycypacji wyborców, bez względu na sposób jej mierzenia, nie musi wskazywać na dobrze funkcjonujący proces wyborczy. Czasami sytuacja jest wręcz odwrotna - w wielu systemach autorytarnych regularnie przeprowadza się wybory, w których poziom frekwencji wyborczej oscyluje w granicach 90\%. Mimo tak wysokiej frekwencji, w państwach, gdzie łamane są zasady wolnych wyborów czy dochodzi do wielu manipulacji na etapie przeliczania głosów - trudno mówić o demokracji.

W kontekście podejmowanych rozważań na temat frekwencji wyborczej warto również wyjaśnić, czym jest absencja wyborcza. Jej mianem określa się zwykle bierność wyborczą, czyli zjawisko nieuczestniczenia uprawnionych obywateli w głosowaniu ${ }^{11}$ - zaniechania udziału w głosowaniu przez osoby do tego uprawnione ${ }^{12}$. Obywateli, którzy nie uczestniczą $\mathrm{w}$ wyborach określa się mianem non-voters.

9 O. Pettersson, Rola instytucji publicznych..., s. 3.

10 A. Żukowski, Systemy wyborcze. Wprowadzenie, Olsztyn 1999, s. 114.

11 A. Żukowski, Absencja wyborcza, w: Encyklopedia politologii, red. W. Sokół, M. Żmigrodzki, t. 1: Teoria polityki, Zakamycze 1999, s. 13.

12 B. Michalak, Absencja wyborcza, w: Leksykon prawa wyborczego, red. B. Michalak, A. Sokala, Warszawa 2010, s. 8. 
W literaturze specjalistycznej wyróżnia się zwykle dwa rodzaje absencji w wyborach. Pierwszą jest absencja wyborcza przymusowa (niezawiniona), związana nie z wolą wyborcy, ale raczej z okolicznościami zewnętrznymi, uniemożliwiającymi czy utrudniającymi partycypację w wyborach. Jak słusznie zauważa Bartłomiej Michalak, taki rodzaj absencji może być konsekwencją następujących sytuacji: ,pominięcie wyborcy w spisie wyborców (na skutek błędu lub w wyniku celowego działania), mimo iż osoba taka jest uprawniona do głosowania; skomplikowany, czasochłonny lub faktycznie dyskryminujący określone grupy społeczne system osobistej rejestracji wyborców; uniemożliwienie głosującym dotarcia do lokalu wyborczego spowodowane jego dużym oddaleniem od miejsca zamieszkania wyborców, położeniem w trudnym lub niebezpiecznym terenie albo niedostosowanymi godzinami pracy; brak możliwości zagłosowania przez osoby pozostające w dniu głosowania czasowo poza miejscem swojego zamieszkania (np. pracujący, studenci, turyści, pacjenci szpitali, aresztanci i więźniowie, żołnierze) lub nieposiadające takiego miejsca (bezdomni); obowiązek głosowania osobistego w przypadku osób niepełnosprawnych, niedołężnych, starszych i obłożenie chorych, dla których prawo wyborcze nie przewiduje alternatywnych sposobów głosowania; nieprzewidziany wypadek losowy"13.

Drugim wskazywanym rodzajem absencji jest tzw. absencja celowa - zawiniona - związana z wolą wyborcy. Na ten rodzaj bierności składa się szereg powodów, ze względu na fakt, iż ten rodzaj nieuczestnieczenia w elekcjach jest wynikiem świadomej i zamierzonej decyzji wyborcy. W tym przypadku przeszkody natury technicznej lub losowej nie odgrywają istotnej roli. Absencja wyborcza celowa spowodowana jest najczęściej zjawiskiem apatii wśród wyborców, którzy nie są zainteresowani sferą polityki, a już na pewno - udziałem w jej kształtowaniu. Oprócz tego, jedną z najczęściej występujących przyczyn bierności wyborców jest „relatywnie wysoki koszt alternatywny głosowania, zarówno samej decyzji wyborczej (konieczność zapoznania się z ofertą polityczną przynajmniej kilku podmiotów wyborczych, śledzenie kampanii wyborczej, wreszcie podjęcie i racjonalizacja decyzji), jak i samego aktu głosowania (czas i zasoby poświęcone na dotarcie do lokalu wyborczego i oddanie głosu); braku opcji politycznej reprezentującej na forum publicznym interesy i poglądy pewnych wyborców" ${ }^{\prime 14}$. Istotnym powodem nieuczestni-

13 Ibidem, s. 8-9.

14 Ibidem, s. 9. 
czenia w głosowaniu może być również brak wiary w to, że za pomocą wyborów można zmienić rzeczywistość polityczną czy społeczną. Wielu wyborców - szczególnie w młodych demokracjach - nie wierzy w siłę pojedynczego głosu - stąd brak aktywności wyborczej. Dodatkowo, brak uczestnictwa w wyborach może być spowodowany brakiem akceptacji dla działalności polityków, którzy w przekonaniu wyborców troszczą się bardziej o swoje interesy, a nie o dobrobyt społeczeństwa.

\section{Frekwencja wyborcza na świecie i w Polsce}

W ciagu ostatnich kilkudziesięciu lat w wielu państwach na świecie obserwuje się spadek poziomu udziału uprawnionych obywateli w wyborach państwowych. Według danych International Institute for Democracy and Electoral Assistance (International IDEA), podczas, gdy od zakończenia II wojny światowej do połowy lat siedemdziesiątych frekwencja w wyborach prezydenckich i parlamentarnych była na poziomie około $75 \%$, to już w latach kolejnych poziom ten spadł poniżej $70 \%$. Jeszcze bardziej widoczny jest spadek partycypacji w wyborach do Parlamentu Europejskiego - średnia frekwencja spadła w tym przypadku z poziomu około 65\% w latach 1976-1990 do około 52\% w kolejnym okresie.

Tabela 1

Średnia frekwencja na świecie w różnych w wyborach (\%)

\begin{tabular}{||c|c|c|c||}
\hline \multirow{2}{*}{ Lata } & \multicolumn{3}{|c||}{ Średnia frekwencja na świecie w różnych w wyborach (\%) } \\
\cline { 2 - 4 } & parlamentarne & prezydenckie & do Parlamentu Europejskiego \\
\hline $1945-1960$ & 77,4 & 74,7 & - \\
\hline $1961-1975$ & 76,7 & 78,6 & - \\
\hline $1976-1990$ & 75,9 & 74,5 & 64,9 \\
\hline $1991-2005$ & 69,9 & 69,5 & $-*$ \\
\hline $2006-2008$ & 66,6 & 68,7 & $-*$ \\
\hline
\end{tabular}

* brak danych - w momencie publikacji dostępne były dane o frekwencji tylko dla dwóch państw. Źródło: IDEA Votem Turnout Database, za: O. Pettersson, Rola instytucji publicznych i organizacji pozarzqdowych $w$ przekazywaniu obywatelom informacji o wyborach - przykłady działań z różnych krajów, International Institute for Democracy and Electoral Assistance (International IDEA), tekst przygotowany na seminarium „Jak skutecznie informować obywateli o wyborach?”, Instytut Spraw Publicznych, Warszawa, 19 czerwca 2009, s. 4.

W tabeli 1 zaprezentowano dane dotyczące frekwencji wyborczej dla wszystkich wyborów do parlamentów narodowych oraz wyborów prezy- 
denckich na świecie, jak również wyborów do Parlamentu Europejskiego w latach 1945-2008.

Wykres 1. Frekwencja wyborcza w państwach Europy Środkowej i Wschodniej

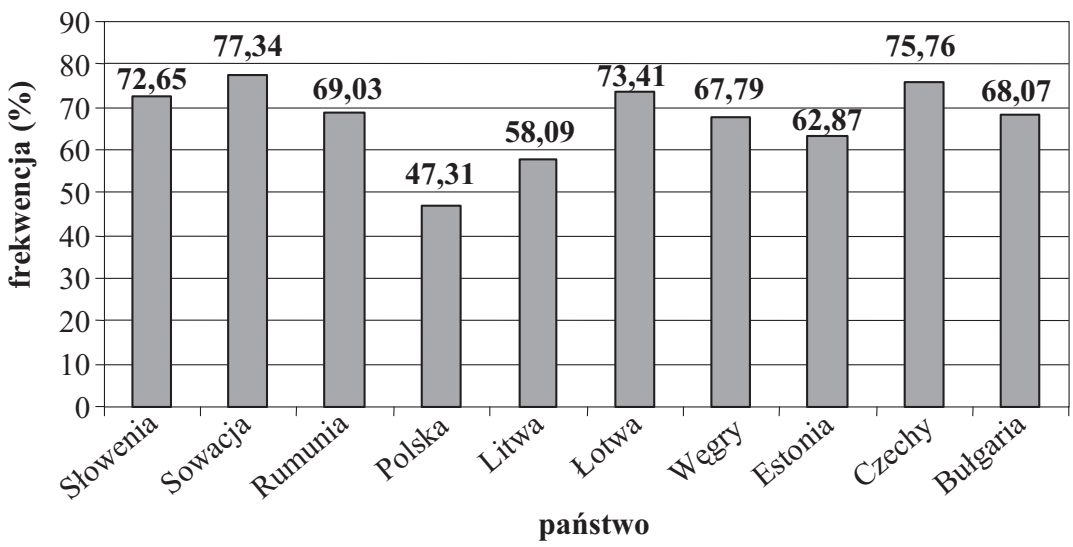

Źródlo: M. Cześnik, Partycypacja wyborcza Polaków, Instytut Spraw Publicznych, Warszawa 2009, s. 6; za: International Institute for Democracy and Electoral Assistance (International IDEA).

Porównanie średnich frekwencji w wyborach parlamentarnych w państwach Europy Środkowej i Wschodniej, będących członkami Unii Europejskiej, pozwala wnioskować, że pod względem aktywności wyborczej obywateli, Polska znajduje się daleko w tyle. W Polsce odnotowano średnią frekwencję w wyborach parlamentarnych na poziomie $47,31 \%$, podczas gdy średnia frekwencja w wyborach do parlamentów narodowych w uwzględnionych na wykresie państwach wynosi średnio ok. $60-70 \%{ }^{15}$.

Dane dotyczące frekwencji wyborczej w Polsce, pozwalają sformułować wniosek, że Polacy za najważniejsze z wyborów traktują wybory prezydenckie - frekwencja jest w nich najwyższa i tylko jeden raz, w I turze w 2005 r. spadła poniżej 50\%. Kształtujący się w ten sposób udział Polaków należy z tłumaczyć faktem głosowania na konkretne znane powszechnie osoby, a nie jedynie na przedstawicieli partii politycznych. Ma to również związek z naturalną polaryzacją wyboru, co zwykle dodatkowo mobilizuje elektorat. Zdecydowanie najmniejszym zaintereso-

15 M. Cześnik, Partycypacja wyborcza Polaków, Instytut Spraw Publicznych, Warszawa 2009, s. 6. 
Wykres 2. Frekwencja wyborcza w Polsce w latach 1989-2010

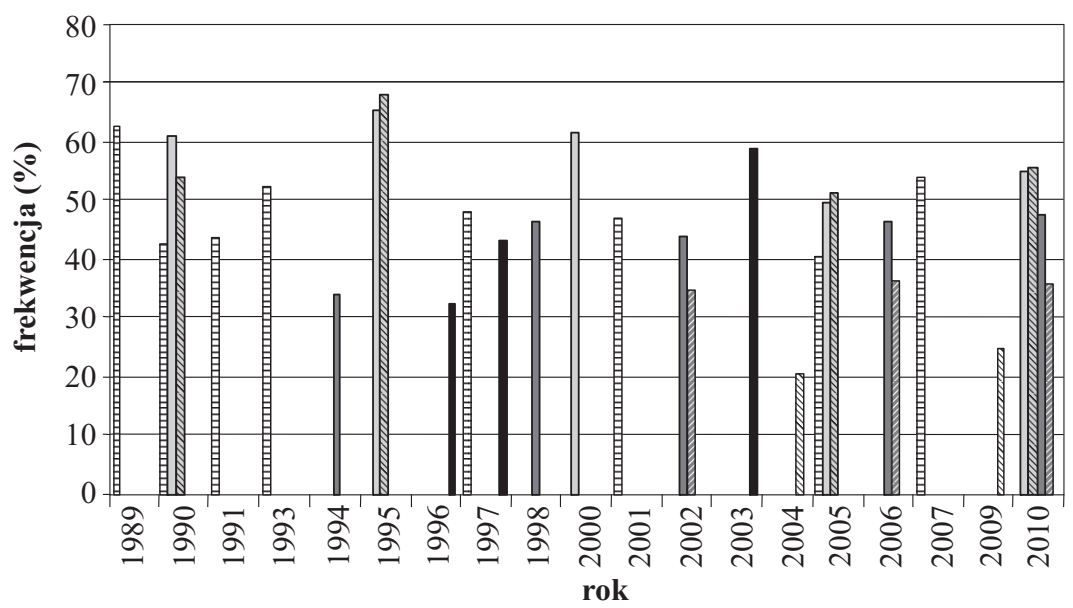

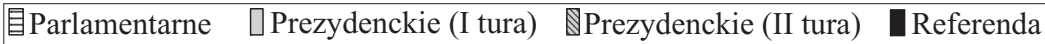
DSamorządowe (I tura) Samorządowe II tura $\mathbb{Q}$ Europejskie

Źródło: Opracowanie własne na podstawie danych Państwowej Komisji Wyborczej.

waniem Polaków cieszą się organizowane do tej pory dwukrotnie wybory do Parlamentu Europejskiego. W nich frekwencja wyborcza osiagnęła poziom nieco ponad 20\% w roku 2004 i nieco ponad 23\% pięć lat później. Niska frekwencja spowodowana jest m.in. traktowaniem tych wyborów jako tzw. second order elections ${ }^{16}$, którym niewątpliwie towarzyszy

16 Według podejścia second-order elections wybory europejskie postrzegane są przez elektorat, partie polityczne czy media jako mniej ważne od first-order elections, czyli od wyborów krajowych, w których wyborcy mają wpływ na skład parlamentu oraz rządu. Cechami charakterystycznymi wyborów „drugiego rzędu” są m.in.: niższa niż w wyborach krajowych spodziewana frekwencja wyborcza, wyborcy są bardziej skłonni do głosowania na tzw. partie protestu lub te, które są na peryferiach sceny politycznej, a nie na partie, które odgrywają największą rolę w życiu politycznym, wyborcy „wykorzystują" wybory second-order do ukarania lub nagrodzenia partii rządzących; K. Reif, H. Schmitt, Nine second-order National elections: a conceptual Framework for the analyses of European Election Results, „European Journal of Political Research" 1980, vol. 8, no. 1, p. 3-4; K. H. Schmitt, R. Mannheimer, About Voting and Non-voting in the European Parliament Elections of June 1989, „European Journal of Political Research" 1991, no. 19, p. 31-54; M. Marsch, Testing the Second-Order Election Model after Four European Elections, „British Journal of Political Science” 1998, no. 28, p. 591-607. 
poczucie dużego dystansu dzielącego wyborcę od instytucji Parlamentu Europejskiego.

Tabela 2

Frekwencja wyborcza w Polsce (lata 1989-2010)

\begin{tabular}{|c|c|c|}
\hline \multicolumn{2}{|c|}{ Wybory / miesiąc rok } & Frekwencja (\%) \\
\hline \multirow[t]{2}{*}{ Parlamentarne / czerwiec 1989} & I tura & 62,5 \\
\hline & II tura & 25,1 \\
\hline Samorządowe / maj 1990 & & 42,3 \\
\hline \multirow[t]{2}{*}{ Prezydenckie / listopad-grudzień 1990} & I tura & 60,6 \\
\hline & II tura & 53,4 \\
\hline Parlamentarne / październik 1991 & & 43,2 \\
\hline Parlamentarne / wrzesień 1993 & & 52,1 \\
\hline Samorządowe / czerwiec 1994 & & 33,8 \\
\hline \multirow[t]{2}{*}{ Prezydenckie / listopad 1995} & I tura & 64,7 \\
\hline & II tura & 68,2 \\
\hline \multicolumn{2}{|c|}{ Referendum uwłaszczenie-wykorzystanie majątku państwa / luty 1996} & 32,4 \\
\hline \multicolumn{2}{|l|}{ Referendum konstytucyjne / maj 1997} & 42,8 \\
\hline \multicolumn{2}{|l|}{ Parlamentarne / wrzesień 1997} & 47,9 \\
\hline \multicolumn{2}{|l|}{ samorządowe / październik 1998} & ok. 46 \\
\hline \multicolumn{2}{|l|}{ Prezydenckie / listopad 2000} & 61,1 \\
\hline \multicolumn{2}{|l|}{ Parlamentarne / wrzesień 2001} & 46,3 \\
\hline \multirow[t]{2}{*}{ Samorządowe / październik-listopad 2002} & I tura & 44,23 \\
\hline & II tura & 35,02 \\
\hline \multicolumn{2}{|l|}{ Referendum akcesyjne / czerwiec 2003} & 58,85 \\
\hline \multicolumn{2}{|l|}{ Europejskie / czerwiec 2004} & 20,42 \\
\hline \multicolumn{2}{|l|}{ Parlamentarne / wrzesień 2005} & 40,57 \\
\hline \multirow[t]{2}{*}{ Prezydenckie / październik 2005} & I tura & 49,74 \\
\hline & II tura & 50,99 \\
\hline \multirow[t]{2}{*}{ Samorządowe / listopad 2006} & I tura & 45,99 \\
\hline & II tura & 36,56 \\
\hline \multicolumn{2}{|l|}{ Parlamentarne / październik 2007} & 53,88 \\
\hline \multicolumn{2}{|l|}{ Europejskie / czerwiec 2009} & 24,43 \\
\hline \multirow[t]{2}{*}{ Prezydenckie 2010 / czerwiec-lipiec 2010} & I tura & 54,94 \\
\hline & II tura & 55,31 \\
\hline \multirow[t]{2}{*}{ Samorządowe / listopad-grudzień 2010} & I tura & 47,32 \\
\hline & II tura & 35,31 \\
\hline
\end{tabular}

Źródło: Opracowanie własne na podstawie danych Państwowej Komisji Wyborczej. 
Udział Polaków w wyborach parlamentarnych pozostaje na stosunkowo niskim poziomie (średnio nie przekracza 48\%). Warto jednak odnotować widoczny wzrost frekwencji w przedterminowych wyborach roku 2007 r. Tak duży (największy po roku 1989) udział elektoratu większość komentatorów thumaczy najczęściej wzrastającym niezadowoleniem z wcześniejszych rządów i chęcią wyrażenia w ten sposób swojego sprzeciwu.

Niski poziom frekwencji wyborczej w Polsce spowodowany jest wieloma czynnikami. Do najczęściej podawanych przyczyn - zgodnie z wynikami wielu badań opinii publicznej - należą: przypisywanie swojemu głosowi niewielkiego znaczenia, brak przekonania o sile sprawczej poszczególnych głosów, brak zainteresowania sferą polityki, protest przeciw rządowi oraz przeciw elitom politycznym, które utraciły w oczach społeczeństwa wiarygodność oraz przeciwko złej sytuacji w kraju. W każdych wyborach część wyborców nie bierze udziału w głosowaniu, mówiąc o swojej absencji jako utrwalonym zwyczaju. Poza wymienionymi wyżej powodami nieuczestniczenia, wielu non-voters wymienia względy obiektywne, uniemożliwiające lub ograniczające możliwość dotarcia do urn (zły stan zdrowia, podeszły wiek, nieobecność w miejscu zamieszkania) $)^{17}$.

\section{Metody zwiększania frekwencji}

Konsekwencją absencji wyborczej jest podejmowanie działań zmierzających do aktywizacji elektoratu. Jakkolwiek uwzględnianie uwarunkowań lokalnych i kultury jest zawsze ważne, wszystkie demokracje, trwałe i te konsolidujące się, muszą starać się zapewnić żywotność swych systemów politycznych oraz zaangażowanie swych obywateli. To wymaga odwrócenia ostatnio obserwowanych spadkowych trendów partycypacji wyborczej oraz narastającego sceptycyzmu wobec polityków i ogólnie instytucji politycznych. W niniejszej części przedstawione zostaną wybrane rozwiązania, które stosowane są w niektórych państwach na świecie i które mogą mieć wpływ na poziom frekwencji wyborczej.

\subsection{Pełnomocnik}

Funkcjonująca w systemie wyborczym m.in. Francji, Belgii czy Wielkiej Brytanii instytucja pełnomocnika bazuje na założeniu, że wyborca,

$17 \mathrm{Na}$ podstawie raportów i komunikatów z badań CBOS-u. 
który z różnych powodów nie może iść do lokalu i oddać głosu, wówczas może upoważnić innego wyborcę, by ten w jego imieniu zgodnie ze wskazówkami oddał głos. Taka osoba upoważniona specjalnym i potwierdzonym dokumentem pełnomocnictwa udaje się do odpowiedniego lokalu wyborczego, pobiera kartę do głosowania, wypełnia ją i wrzuca do urny wyborczej $^{18}$. Instytucja pełnomocnika została powołana, by ułatwić głosowanie wąskim grupom wyborców. Zwykle chodzi tu o osoby starsze, chore, niepełnosprawne, a także o wojskowych czy urzędników państwowych, którzy w momencie wyborów przebywają w pracy poza miejscem zamieszkania w kraju czy za granica.

W Polsce - mimo wielu prób ukonstytuowania instytucji pełnomocnika wyborczego - instytucja ta po raz pierwszy wprowadzona została dopiero w wyborach prezydenckich roku $2010^{19}$. Możliwość głosowania przez pełnomocnika dostępna była również przy okazji wyborów samorządowych jesienią 2010. Na mocy znowelizowanej pod koniec roku 2009 Ustawy o wyborze Prezydenta Rzeczpospolitej Polskiej ${ }^{20} \mathrm{w}$ artykule 49 przewidziano możliwość głosowania przez pełnomocnika. Od tego czasu osoby powyżej 75 roku życia oraz niepełnosprawni w stopniu znacznym i umiarkowanym mogą w ten sposób uczestniczyć w głosowaniu ${ }^{21}$.

18 J. Zbieranek, W stronę reformy procedur głosowania w Polsce, w: Aktywny obywatel, nowoczesny system wyborczy, red. L. Kolarska-Bobińska, J. Kucharczyk, J. Zbieranek, Warszawa 2006, s. 19-20.

${ }_{19}$ Rozporzadzenie z dnia 21 kwietnia 2010 r. w sprawie sporzadzenia aktu petnomocnictwa do głosowania w wyborach Prezydenta Rzeczypospolitej Polskiej (Dz. U. $\mathrm{Nr} 66$, poz. 426) określa szczegółowy tryb postępowania w sprawie sporządzania takich aktów, wzory wniosku, aktu pełnomocnictwa i dokumentu zawierającego zgodę na przyjęcie pełnomocnictwa do głosowania, a także wzór i sposób prowadzenia aktualizacji prowadzonego przez urząd gminy wykazu sporządzonych pełnomocnictw. Głosowanie przez pełnomocnika osobom posiadającym orzeczenie o znacznym lub umiarkowanym stopniu niepełnosprawności albo równoznaczne orzeczenie organu rentowego, a także osobom, które najpóźniej w dniu głosowania kończą 75 lat, umożliwiła nowelizacja ustaw wyborczych z dnia 19 listopada 2009 r. Pełnomocnictwa do głosowania udziela się przed wójtem (burmistrzem, prezydentem miasta) lub przed innym upoważnionym pracownikiem urzędu gminy.

20 Ustawa z dnia 27 września 1990 r. o wyborze Prezydenta Rzeczypospolitej Polskiej, tekst jednolity: Dz. U. 2010, Nr 72, poz. 467.

21 Seniorzy i niepetnosprawni moga głosować przez petnomocnika, 29.05.2010, Wiadomości24.pl. Największy serwis dziennikarstwa obywatelskiego, http://www.wiadomosci24.pl/artykul/seniorzy_i_niepelnosprawni_moga_glosowac_przez_pelnomocnika_140740.html, 30.03.2011, 
Zgodnie z nowym Kodeksem wyborczym ${ }^{22}$ ta forma partycypowania możliwa będzie w każdych wyborach.

Obywatel, który chce ustanowić pełnomocnika, musi uczynić to przed wójtem, burmistrzem lub prezydentem miasta [lub też przed pracownikiem gminy, upoważnionym przez wójta (burmistrza, prezydenta miasta) do sporządzania aktów pełnomocnictwa do głosowania] w gminie, w której jest on wpisany do rejestru wyborców. Zainteresowany wypełnia wówczas odpowiedni wniosek, do którego załączona winna być pisemna zgoda - potencjalnego pełnomocnika (oraz kopia zaświadczenia o prawie do głosowania wydanego tej osobie, ale tylko w przypadku, gdy osoba ta nie jest wpisana do rejestru wyborców w tej samej gminie, co udzielający pełnomocnictwa do głosowania).

W przypadku osób niepełnosprawnych w stopniu umiarkowanym lub znacznym wraz z wnioskiem o ustanowienie pełnomocnika dostarczyć należy dokument poświadczający stopień niepełnosprawności osoby wnioskującej.

Warto zwrócić uwagę na fakt, iż głosowania przez pełnomocnika nie przeprowadza się w obwodach utworzonych na terenie szpitali, domów pomocy społecznej, zakładów karnych, aresztów oraz ich oddziałów zewnętrznych ${ }^{23}$.

\subsection{Głosowanie przez osobę upoważnioną}

W tym modelu inny wyborca może jedynie pobrać w imieniu wyborcy pakiet z materiałami wyborczymi, dostarczyć go do miejsca zamieszkania wyborcy, a po oddaniu przez niego głosu - przekazać do właściwej komisji wyborczej.

Głosowanie z pomocą osoby upoważnionej jest swoistą uproszczoną wersją głosowania przez pełnomocnika, jak i dwu innych rozwiązań - omówionych poniżej: głosowania korespondencyjnego i tzw. „wędrującej urny wyborczej”. Osoba upoważniona pomocna zwykle jest osobom niepełnosprawnym czy chorym, które mogłyby skorzystać z pomocy osób, które się nimi opiekują.

22 Ustawa z dnia 5 stycznia 2011 r. - Kodeks wyborczy, Dz. U. 2011, Nr 21 poz. 112.

23 A. Kiersztyn, Zastępstwo przy urnie, Extra Polska, http://extrapolska.pl/index.php?option $=$ com_content $\&$ view $=$ article $\&$ id $=4280 \% 3$ Azastpstwo-przy-urnie \&catid=170\%3Awybrane-z-numeru\&Itemid=245, 15.03.201. 


\subsection{Instytucja „wędrującej urny wyborczej"}

„Wędrująca urna” opiera się na możliwości dostarczenia urny wyborczej do miejsca zamieszkania wyborcy i oddania tam przez niego głosu; Takie rozwiązanie funkcjonuje m.in. w Chorwacji, Czechach, Danii, Słowenii, na Litwie, Łotwie czy Ukrainie. Instytucja ta skierowana jest przede wszystkim do osób, które są niepełnosprawne, starsze, czy obłożnie chore - nie mogą udać się do lokalu wyborczego. Osoby zainteresowane zagłosowaniem $\mathrm{w}$ domu, w ustalonym ustawowo terminie muszą złożyć odpowiedni wniosek we właściwej komisji wyborczej - np. w Słowacji termin ten mija trzy dni przed wyborami. Tak ustalone ramy czasowe pozwalają stworzyć listy wyborców, do których ma udać się komisja wyborcza z urną wyborczą o niewielkich rozmiarach, umożliwiających jej przenoszenie. Komisja wyborcza wyposażona jest również w materiały wyborcze. Po zakreśleniu odpowiedniej opcji, wyborca wrzuca wypełnioną kartę do urny wyborczej. Instytucja „wędrującej urny wyborczej” jest często krytykowana przez specjalistów prawa wyborczego - głównie ze względu na wiele trudności natury technicznej i organizacyjnej, które mogą zaważyć na bezpieczeństwie wyników wyborów. Jak zauważa Jarosław Zbieranek, brak skutecznego zabezpieczenia „wędrujących urn wyborczych" w 2004 r. na Ukrainie podczas wyborów prezydenckich może podważać wyniki elekcji i prowadzić do ich sfałszowania ${ }^{24}$.

\subsection{Głosowania korespondencyjne}

Ten sposób głosowania polega na tym, że wyborca jeszcze przed dniem wyborów otrzymuje od komisji wyborczej przesyłkę (tzw. pakiet wyborczy), w której znajdują się materiały wyborcze - m.in. karta do głosowania wraz z instrukcją głosowania, odpowiednio zaadresowana koperta zwrotna.

Procedura ta przewidziana jest w prawie wyborczym wielu państw Unii Europejskiej, m.in. w Austrii, Belgii, Danii, Finlandii, Hiszpanii, Irlandii, Estonii, Litwie, Wielkiej Brytanii czy w Republice Federalnej Niemiec. Głosowanie korespondencyjne jest również stosowane w Stanach Zjednoczonych - ta formuła dotyczy osób, które w dniu wyborów przeby-

24 J. Zbieranek, W stronę reformy procedur..., s. 22. 
wają poza granicami kraju. Wówczas jednostką pośredniczącą i koordynującą jest amerykańska ambasada lub konsulat, których pracownicy instruują wyborców co do procedury głosowania korespondencyjnego, rejestracji, odesłania karty wyborczej ${ }^{25}$.

Również w Szwajcarii istnieje możliwość głosowania korespondencyjnego, z tym jednak zastrzeżeniem, iż mogą z niego skorzystać wszyscy wyborcy. W związku z tym, że Szwajcarzy mają możliwość głosowania w ciagu roku przynajmniej kilkakrotnie (głównie w różnego rodzaju referendach federalnych, kantonalnych czy lokalnych), w latach osiemdziesiątych i dziewięćdziesiątych zaczęto obserwować w tym państwie spadkową tendencję udziału uprawnionych w procedurach wyborczych, co tłumaczone było przez wielu specjalistów swoistym znużeniem Szwajcarów taką liczbą głosowań. Obserwując ten trend Rada Federalna (rząd) oraz Rada Narodowa i Rada Kantonów (izby parlamentu) podjęły decyzje, mające na celu zmianę kierunku zachowań wyborców, udostępniając im nową metodę oddawania głosów. Głosowanie korespondencyjne (za pomocą poczty) miało uczynić sam akt głosowania krótszym, wygodniejszym i bardziej dostępnym. Nowe rozwiązanie sprawdziło się, a pod koniec lat dziewięćdziesiątych zauważalny był kilkuprocentowy wzrost frekwencji wyborczej zarówno w wyborach, jak i referendach. Obecnie frekwencja wyborcza w Szwajcarii oscyluje w granicach 35-55\%, co biorąc pod uwagę liczbę głosowań w ciagu roku, jest wynikiem relatywnie dobrym.

W Polsce do roku 2011 nie funkcjonowało rozwiązanie głosowania za pośrednictwem poczty. Na mocy nowo-uchwalonego Kodeksu wyborczego $^{26}$ wprowadzono głosowanie korespondencyjne. Wyborca przebywający w dniu wyborów za granicą i posiadający ważny polski paszporty wpisany może zostać do spisu wyborców, który sporządzany jest przez właściwego terytorialnie konsula. Uwzględnienie w spisie wyborców dokonywane jest na podstawie osobistego zgłoszenia wniesionego w formie ustnej, pisemnej, telefonicznie, telefaksem lub też drogą elektroniczną. Prawo do głosowania zagwarantowane jest tylko na podstawie wpisu do

25 Głosowanie korespondencyjne za granica, Ambasada Stanów Zjednoczonych Ameryki, http://polish.poland.usembassy.gov/poland-pl/visa_requirements/gosowanie-korespondencyjne-za-granic.html, 31.03.2011; Federal Voting Assistance Program, http://www.fvap.gov/index.html, 31.01.2011.

${ }^{26}$ Ustawa z dnia 5 stycznia 2011 r. - Kodeks wyborczy, Dz. U. 2011, Nr 21, poz. 112. 
spisu wyborców ${ }^{27}$. Aby zagłosować korespondencyjnie wyborca musi zgłosić zamiar takiego głosowania do 15 dnia przed dniem wyborów.

Na mocy art. 65 niezwłocznie po otrzymaniu od właściwej komisji wyborczej kart do głosowania (nie później niż do 10 dnia przed dniem wyborów) konsul wysyła do wyborców chcących głosować korespondencyjnie pakiet wyborczy, który zawiera: zaadresowaną kopertę zwrotna, kartę bądź karty do głosowania, kopertę na kartę bądź karty do głosowania, oświadczenie o osobistym i tajnym oddaniu głosu na karcie do głosowania oraz instrukcje głosowania ${ }^{28}$.

Wprowadzenie do polskiego systemu wyborczego możliwości głosowania korespondencyjnego uznać należy za bardzo istotne przedsięwzięcie z punktu widzenia frekwencji wyborczej. Należy mieć na względzie fakt, iż Polacy przebywający na emigracji bardzo rzadko uczestniczą w państwowych elekcjach: czy to wyborach (zarówno parlamentarnych, prezydenckich, jak i samorządowych), czy referendach, a jeszcze rzadziej w wyborach do Parlamentu Europejskiego. Rzeczywista frekwencja wyborcza wśród tej grupy wyborców jest bardzo niska i zwykle osiaga poziom kilku procent. Na potwierdzenie warto zwrócić uwagę na to, że w wyborach do Sejmu RP roku 2007 czy prezydenckich roku 2010 głosowało odpowiednio nieco ponad 149 tys. oraz 169 tys. w I turze i 203 tys. uprawnionych obywateli w II turze, podczas gdy zgodnie z szacunkami Głównego Urzędu Statystycznego poza granicami kraju przebywało w tym czasie ok. 2 mln Polaków. Tak mały udział polskich obywateli przybywających za granicą $\mathrm{w}$ wyborach państwowych spowodowany jest m.in. małą liczbą lokali wyborczych - najczęściej ulokowanych w placówkach ambasad lub konsulatów, co z kolei nie uwzględnia dużego „rozproszenia polskich obywateli przebywających poza granicami kraju i jest niedostosowane do ich potrzeb" ${ }^{\prime 29}$.

\subsection{Więcej obwodów głosowania}

Tworzenie dodatkowych obwodów głosowania jest szczególnie istotne z punktu widzenia wyborców przebywających poza granicami kraju.

27 Ibidem, Rozdział 8. Głosowanie korespondencyjne w obwodach głosowania utworzonych za granica, art. 62-68.

28 Ibidem, art. 65.

29 J. Zbieranek, Gtosowanie korespondencyjne-procedura dla polskich obywateli przebywajacych za granica, Instytut Spraw Publicznych, http://www.isp.org.pl/files/14145899420501325001287414049.pdf, 15.03.2011. 
Biorąc pod uwagę liczbę Polaków, którzy po wstąpieniu Polski do Unii Europejskiej wyjechali głównie do Wielkiej Brytanii i Irlandii w celach zarobkowych oraz fakt, iż mogą oni głosować głównie w nielicznych placówkach dyplomatycznych, rozwiązanie to wydaje się szczególnie przydatne.

\subsection{Dwudniowe głosowanie}

Wydłużenie głosowania do dwóch dni czy to podczas wyborów, czy referendum jest kolejnym istotnym manewrem mającym przełożyć się na zwiększenie frekwencji wyborczej. Rozwiązanie to jest stosowane m.in. w Republice Czeskiej. W 2003 r. przy okazji referendum w sprawie akcesji do UE przeprowadzono w Czechach dwudniowe głosowanie referendalne. Podobnie w Polsce - na mocy poprawek do ustawy o referendum ogólnokrajowym umożliwione zostało dwudniowe referendum ${ }^{30}$. W konsekwencji 7-8 czerwca 2003 r. przeprowadzono referendum akcesyjne, w którym po raz pierwszy obywatele mogli głosować w czasie dwóch dni. Powodem zorganizowania takiego wydłużonego głosowania była potrzeba przekroczenia progu $50 \%$ frekwencji, która niezbędna była dla wiążącego charakteru referendum.

Polski Kodeks wyborczy w art. 43 umożliwia głosowanie dwudniowe, które może być przeprowadzone przy okazji wszystkich państwowych elekcji $^{31}$.

\subsection{Głosowanie przedterminowe (advance voting)}

Głosowanie przedterminowe jest rozwiązaniem wygodnym dla wszystkich wyborców, którzy z różnych przyczyn nie będą w swoim miejscu zamieszkania w dniu wyborów. Ta forma pozwala na oddanie głosu we wcześniej wyznaczonych lokalach wyborczych w dłuższym okresie przed dniem wyborów. Takie rozwiązanie stosowane jest na przykład w Estonii.

30 Referendum ogólnokrajowe może trwać dwa dni-w sobotę i niedzielę-zdecydowat Sejm, 14.05.2009, Money.pl, http://www.money.pl/gospodarka/wiadomosci/artykul/referendum;ogolnokrajowe;moze;trwac;dwa;dni;-;w;sobote;i;niedziele;-;zdecydowal;sejm,231,0,58343.html, 11.12.2009.

31 Ustawa z dnia 5 stycznia 2011 r. - Kodeks..., op. cit., art. 43. 
$\mathrm{Na}$ stronach Internetowych Estońskiej Komisji Wyborczej umieszczono informację na temat głosowania przedterminowego, dzieląc je na trzy kategorie:

- głosowanie przedterminowe w okręgu wyborczym osoby uprawnionej (możliwe od szóstego do trzeciego dnia przed dniem wyborów);

- głosowanie przedterminowe poza okręgiem wyborczym osoby uprawnionej (jeśli wyborca w tygodniu poprzedzającym wybory jest poza miejscem swojego zamieszkania, wówczas ma on możliwość głosowania poza okręgiem wyborczym. W tym celu, każda gmina wiejska i miejska mają co najmniej po jednym specjalnym lokalu wyborczym przeznaczonym do głosowania przedterminowego osobom spoza danego okręgu - możliwe od szóstego do trzeciego dnia przed dniem wyborów);

- głosowanie przedterminowe poza okręgiem wyborczym osoby uprawnionej - w miejscu przebywania osoby uprawnionej (np. w szpitalu, domu opieki itd. możliwe od szóstego do trzeciego dnia przed dniem wyborów) ${ }^{32}$.

\subsection{Kampanie informacyjne i promocyjne (profrekwencyjne)}

Istotną rolę w aktywizowaniu wyborców odgrywają kampanie społeczne. Kampanie o charakterze informacyjnym mają na celu dostarczenie najważniejszych informacji na temat wyborów: sposobu, czasu i miejsca głosowania. Jak zauważa O. Pettersson ,większość organów zajmujących się organizacją wyborów (Electoral Management Bodies - EMBs) przeprowadza kampanie informacyjne, które na ogół obejmują wszystkie aspekty, chociaż częstą praktyką jest uzupełnianie głównej kampanii informacyjnej konkretnymi działaniami skierowanymi do grup mniej skłonnych do głosowania"33.

Z kolei kampanie promocyjne skupiają się na tym dlaczego głosować. Apolityczne kampanie reklamowe bazują na przekonaniu wyborców, że głos każdej osoby się liczy i ma siłę wpłynąć na rzeczywistość w państwie. Organizatorzy tych kampanii próbują również przypomnieć wyborcom, iż obywatelskim obowiązkiem jest uczestnictwo w wyborach.

32 Advance Voting, Estonian National Electoral Committee, http://www.vvk.ee/voting-methods-in-estonia/voting-in-advance, 15.03.2011.

33 O. Pettersson, Rola instytucji publicznych..., s. 8. 
Najczęściej kampanie promocyjne przeprowadzane są przez organy kierujące organizacją wyborów oraz organizacje pozarządowe. W Polsce już kilkakrotnie organizowane były społeczne kampanie profrekwencyjne pod hasłem: „Masz głos, masz wybór” czy „Zmień kraj. Idź na wybory”. Warto przy tym zaznaczyć, iż kampania „Zmień kraj...” wpłynęła istotnie na decyzję o udziale w wyborach, przede wszystkim wśród młodszych wyborców ${ }^{34}$.

\subsection{Głosowanie obowiąkowe}

Większość demokratycznych rządów uznaje udział w wyborach krajowych za prawo każdego obywatela. Niektóre jednak traktują partycypację w wyborach jako wyraz obywatelskiej odpowiedzialności wyborców.

W państwach, gdzie głosowanie postrzegane jest jako obowiązek, prawnie ustanowiono głosowanie obligatoryjne, które jest regulowane w ustawie zasadniczej lub (i) w ustawach wyborczych. Co ciekawe, w niektórych krajach ustawodawca przewiduje sankcje dla osób, które nie uczestniczą w wyborach.

Obowiązek głosowania nie jest nowym elementem procesu wyborczego - pierwszymi państwami, gdzie wprowadzono głosowanie obowiązkowe były Belgia (1892 r.), Argentyna (1914 r.) czy Australia (1924 r.). Niektóre kraje - np. Holandia czy Wenezuela w swojej historii stosowały obligatoryjne głosowanie, jednak z tego rozwiązania zrezygnowały odpowiednio w 1967 r. i w 1993 r.

Zwolennicy tej formy głosowania twierdzą, że decyzje podejmowane przez demokratycznie wybrane rządy - dzięki głosowaniu obligatoryjnemu mają większą legitymizację, ponieważ zostały podjęte (oczywiście w sposób pośredni) przez większą liczbę uprawnionych do głosowania i to jest największy atut tej formy partycypacji w procesie podejmowania decyzji państwowych. Z kolei głównym argumentem podawanym przez przeciwników głosowania obowiązkowego jest to, że przeczy ono demokratycznej wartości, jaką jest wolność. Głosowanie w wyborach nie jest faktycznym obowiązkiem, a egzekwowanie tego prawa jest naruszeniem wolności obywatelskiej. Obowiązek głosowania z punktu widzenia elek-

34 Zmień kraj. Idź na wybory. Raport o przebiegu kampanii i rekomendacje na przyszłość, s. 23. 
toratu, może wpływać w negatywny sposób na edukację obywateli i zniechęcać ich do rzeczywistego zaangażowania w procesy polityczne.

Warto nadmienić, iż w państwach, gdzie obowiązuje głosowanie obligatoryjne, za nieuczestniczenie w elekcjach stosowane są różnego rodzaju sankcje:

- wytłumaczenie się wyborcy z absencji w wyborach po to, by uniknąć kolejnych sankcji - jeśli takowe istnieją (m.in. Argentyna, Australia, Belgia, Chile, Cypr, Lichtenstein, Luksemburg, Turcja);

- kara pieniężna, której wymiar jest różny w różnych państwach (za złamanie obowiązku głosowania w Belgii obowiązuje kara od 25-50 euro i nawet kilka razy więcej, plus dodatkowo pozbawienie praw publicznych w przypadku recydywy ${ }^{35}$; w Argentynie 10-20 argentyńskich pesos, 20 soli w Peru);

- pozbawienie wolności - osoba nieuczestnicząca w wyborach może zostać pozbawiona wolności w przypadku, gdy nie zapłaci grzywny, która nałożona została na niego w wyniku absencji wyborczej. Sytuacja taka może mieć miejsce, gdy ukarany grzywną wyborca mimo upomnienia nie zapłaci kary lub gdy kilkakrotnie odmówi zapłacenia grzywny. Takie rozwiązanie obowiązuje w Chile i Egipcie;

- pozbawienie praw obywatelskich lub wywłaszczenie. Przykładem jest Belgia, gdzie wyborca po czterokrotnej absencji wyborczej w ciagu 15 lat może zostać pozbawiony praw wyborczych. W Singapurze taki wyborca jest usuwany z rejestru wyborców do czasu aż wystapi z wnioskiem o ponowne wpisanie do rejestru, podając przy tym przyczyny absencji w poprzednich głosowaniach. W Boliwii natomiast biorący udział w głosowaniu otrzymują zaświadczenie o uczestnictwie - bez tego dokumentu wyborca może nie otrzymać swojej wypłaty;

- inne sankcje, do których można zaliczyć trudności w znalezieniu pracy w sektorze publicznym (Belgia), a także tzw. „nieszkodliwe sankcje” polegające na problemach $\mathrm{z}$ otrzymaniem miejsca w przedszkolu dla dziecka osoby niegłosującej (Włochy). Te sankcje z reguły nie są uregu-

35 W praktyce - jak podaje Polska Agencja Prasowa - kary grożą Belgom tylko na papierze. W 2010 r. władze belgijskie ujawniły, że od 2003 roku żaden Belg nie został pociągnięty do odpowiedzialności za nieuczestniczenie w wyborach. Jest to wynikiem tego, że prokuratura nie chce zrzucać na sądy dodatkowej pracy. Te bowiem nie radzą sobie ze zbyt dużą liczbą spraw; Belgia: Obowiazkowe głosowanie do lamusa?, 19.02.2010, http://info.wiara.pl/doc/440879.Belgia-Obowiazkowe-glosowanie-do-lamusa, 2.04.2011. 
lowane prawnie. W niektórych państwach nie stosuje się żadnych sankcji za nieuczestniczenie w wyborach.

\subsection{E-voting}

Jednym z narzędzi nowej formy sprawowania władzy jest tzw. głosowanie elektroniczne, które spotyka się z coraz większym zainteresowaniem.

Zgodnie z definicją e-voting „oznacza głosowanie za pomocą środków elektronicznych"36. W literaturze wyróżnia się dwa rodzaje takiego głosowania: głosowanie elektroniczne (e-voting, tzw. e-głosowanie) oraz głosowanie internetowe (i-voting, tzw. i-głosowanie). E-głosowanie to pojęcie szersze znaczeniowo i zawiera w sobie formę głosowania internetowego. Głosowanie elektroniczne w praktyce odnosi się do wykorzystywania w procesie techniki wyborczej m.in.: telewizyjnych platform cyfrowych, telefonii, Internetu ${ }^{37}$. Głosowanie internetowe dzieli się na dwie kategorie: Internet Voting at the Polling Place ${ }^{38}$ oraz Remote Internet Voting ${ }^{39}$.

Popularność głosowania elektronicznego wzrasta przede wszystkim dlatego, że jest ono nowym, potencjalnie korzystnym i wygodnym zjawiskiem dla setek milionów ludzi na całym świecie. Wielu wyborców bardziej preferuje e-głosowanie (w szczególności głosowania online) niż metody tradycyjne - do tej grupy należą zapewne najmłodsi wyborcy ${ }^{40}$.

36 A. Kaczmarczyk, R. Czajkowski, E-Głosowanie - niezbędny element elektronicznej platformy do obstugi procedur $w$ demokracji w społeczeństwie informacyjnym. E-vote-an essential element of electronic platform for services for democratic procedures in the Information Society, referat prezentowany na konferencji „Tworzenie mechanizmów i struktur rozwoju elektronicznej gospodarki w Polsce", Warszawa, 12.06.2001, s. 50, http://www.logistyka.net.pl/images/articles/1375/Ref-Czajkowski.doc, 13.11.2007.

37 M. Nowina-Konopka, Elektroniczna urna, http://www.rpo.gov.pl/pliki/ 12066058070.pdf, 27.11.2008.

38 Internet Voting at the Polling Place dzięki któremu wyborcy oddają głos w specjalnie do tego przygotowanym miejscu z wykorzystaniem kanału, jakim jest Internet.

39 Remote Internet Voting - to zdalny sposób oddawania głosu, dzięki któremu wyborca głosuje bądź to z ,kiosku wyborczego”, bądź z domowego komputera podłączonego do Internetu. Internetem przesyłane są dane do centralnej bazy danych z obydwu typów stanowisk.

${ }^{40}$ The I's Have It, http://www.everyonecounts.com/index.php/why_everyone_counts/why_i-voting, 14.02.2010. 
W toku niniejszych rozważań na temat implementacji e-votig należy podkreślić, że celem wdrażania głosowania elektronicznego nie jest zastąpienie tradycyjnego sposobu uczestniczenia w wyborach nową procedurą. Głównym założeniem zwolenników e-voting jest dodanie alternatywnej drogi udziału, a przez to zwiększenia dostępności do procesu głosowania dla szerszej rzeszy obywateli, w tym osób niepełnosprawnych, osób mieszkających lub pracujących za granicą.

Jednym z najważniejszych przykładów państw, w którym wprowadzono głosowanie elektroniczne jest Estonia, gdzie wyborcy moga głosować online. Władze estońskie twierdzą, że tzw. Remote Internet Voting jest oczekiwaną społecznie, zaakceptowaną cechą procesu wyborczego w tym kraju, która to cecha jest bardzo istotna z punktu widzenia zaangażowania elektoratu ${ }^{41}$. Potwierdzają to dane Estońskiej Komisji Wyborczej - frekwencja w wyborach parlamentarnych wzrosła z 58,2\% w roku 2003 do $61,9 \%$ w roku 2009, a w wyborach do Parlamentu Europejskiego z 26,8\% w 2004 r. do $43,9 \%$ w roku $2009^{42}$. Ponadto, coraz większy udział i-głosów (głosów oddanych online) w strukturze wszystkich oddanych głosów w wyborach, potwierdzać może wysoki poziom zaufania społeczeństwa estońskiego do nowych metod wyborczych. Nie zaskakuje przy tym fakt, iż wyborcy, którzy zdecydowali się na głosowanie internetowe szczycą się nieco szerszą wiedzą na temat komputerów czy Internetu. Jak zaznaczono w kanadyjskim raporcie pt. A Comparative Assessment of Electronic Voting, 20\% i-wyborców (wyborców głosujących za pośrednictwem Internetu) w roku 2005 stwierdziło, że gdyby nie miało możliwości głosowania internetowego, najprawdopodobniej w ogóle nie uczestniczyłoby w wyborach. W roku 2007 natomiast $11 \%$ zadeklarowało, że prawdopodobnie lub z pewnością nie zagłosowałoby w wyborach, gdyby nie opcja i-głosowania. Dane te wskazują zatem, że możliwość głosowania przez Internet może mieć wpływ na zaangażowanie wyborcze

41 N. Goodman, J. H. Pammett, J. DeBardeleben, J. Freeland, A Comparative Assessment of Electronic Voting, Strategic Knowledge Cluster Canada-Europe Transatlantic Dialogue, Carlton University, February 2010, s. 3, http://www.carleton.ca/europecluster/events/2010-01-26-InternetVotingMaterials/AComparativeAssessmentofInternetVotingFINALFeb19-a.pdf, 14.02.2011.

42 Voter turnout data for Estonia, International Institute for Democracy and Electoral Assistance (International IDEA), http://www.idea.int/vt/country_view.cfm?country=EE, 1.12.2010; Estonian National Electoral Committee, http://www.vvk.ee/, 1.12.2010. 
społeczeństwa, szczególnie na aktywność tych, którzy nie uczestniczą zwykle w procedurach wyborczych ${ }^{43}$.

Również w innych państwach stosowano lub rozważa się zastosowanie różnych form e-voting. Za przykłady posłużyć mogą Stany Zjednoczone, Wielka Brytania czy Holandia. Warto również pamiętać o Szwajcarii, gdzie w latach 2000-2005 wdrażano trzy projekty pilotażowe - Genewa, Neuchâtel, Zurych - oparte na wykorzystaniu ICT w procedurach głosowania na szczeblach lokalnym, kantonalnym i federalnym. Głównym celem wprowadzenia e-voting (pomijając znaczną redukcję kosztów) było przede wszystkim dostosowanie procedur politycznych do rozwoju społeczeństwa, ale i dodanie (do form tradycyjnych - przy urnach i przy pomocy poczty) nowej, atrakcyjnej formy partycypowania w wyborcach i referendach. Jednym z celów wprowadzenia systemu e-voting było także wpłynięcie na wzrost partycypacji z jednej strony, a z drugiej - zmniejszenie dystansu między procedurami demokratycznymi a obywatelami ${ }^{44}$.

\section{Podsumowanie}

Problematyka zwiększania frekwencji wyborczej staje się w debacie nad systemami wyborczymi coraz bardziej doniosła. Spadek poziomu partycypacji uprawnionych w wyborach praktycznie na całym świecie składnia wielu naukowców i specjalistów od procedur wyborczych do prowadzenia badań nad aktywnością wyborców oraz do szukania rozwiązań, które mogłyby zachęcić obywateli do udziału w głosowaniach państwowych. Włączanie do procedury głosowania coraz większej liczby uprawnionych obywateli oraz umożliwienie im podejmowania w ten sposób decyzji o istotnych z punktu widzenia państwa sprawach jest trzonem demokracji i bez wątpienia może przełożyć się na wzrost frekwencji wyborczej. Przedstawione w niniejszej pracy rozwiązania mają potencjał wpłynięcia na partycypację elektoratu, jednak niemożliwym jest jednoznaczne stwierdzenie, w jakim stopniu frekwencja wyborcza może się zmienić w wyniku implementacji nowych procedur. Prowadzone badania nad poziomem uczestnictwa obywateli nie dają jasnej odpowiedzi, czy np.

43 N. Goodman, J. H. Pammett, J. DeBardeleben, J. Freeland, A Comparative Assessment..., s. 35 .

44 N. Braun, E-Voting: Switzerland's projects and their legal framework-in a European context, Swiss Federal Chancellery, www.admin.ch/e-gov, 17.03.2011. 
dwudniowe głosowanie lub głosowanie przez pełnomocnika lub online wpływa na wzrost frekwencji wyborczej. Z pewnością dodatkowe formy głosowania mogą okazać się wygodne dla obywateli.

Jeśli chodzi o frekwencję wyborczą w Polsce, to przypomnieć należy, iż obowiązujący od 2011 r. Kodeks wyborczy przewiduje cztery niezwykle istotne z punktu widzenia udziału obywateli rozwiązania. W Kodeksie przewiduje się, że organ zarządzający wybory każdorazowo zadecyduje, czy wybory będą jednodniowe, czy też będą trwały dwa dni. Ponadto, ujednolicone zostały godziny trwania głosowania: wybory zawsze odbywać się będą w tych samych godzinach (pomiędzy godziną 7 a 21). Co niezwykle istotne, w kontekście samego sposobu oddawania głosu przez wyborców np. chorych oraz przebywających za granicą - prócz głosowania w lokalu wyborczym wprowadzone zostały dwie nowe formy: głosowanie przez pełnomocnika oraz głosowanie korespondencyjne.

Mimo faktu, iż w polskiej debacie - szczególnie ostatnio - coraz częściej pojawia się kwestia wprowadzenia głosowania elektronicznego jako dodatkowego narzędzia oddawania głosów, to jednak ze względu na słabą infrastrukturę i fakt, iż wielu wyborców nadal nie ma dostępu do Internetu - implementacja e-voting w Polsce wydaje się być perspektywą dość odległą w czasie. Warto jednak pamiętać, iż mimo stale istniejących problemów związanych m.in. z zabezpieczeniem internetowych wyborów, pozytywne doświadczenia coraz większej liczby państw mogą okazać się pozytywnym bodźcem do wprowadzania e-voting.

\section{Summary}

Numerous reports and analyses of voter turnout levels have recorded the global trend of declining participation by citizens in national elections. One of the most important results of poor participation of citizens in electoral processes is the serious legitimization deficit. Governments in many countries try to prevent that by taking various measures to solve the problem of falling turnout and to increase the level of the electorate's involvement. In Poland, the low turnout level has been the subject of many scholarly discussions aimed at finding solutions to the problem of poor civic participation. The main goal of this study is to assess the various methods of increasing voter turnout which are used in different countries, including Poland. 
